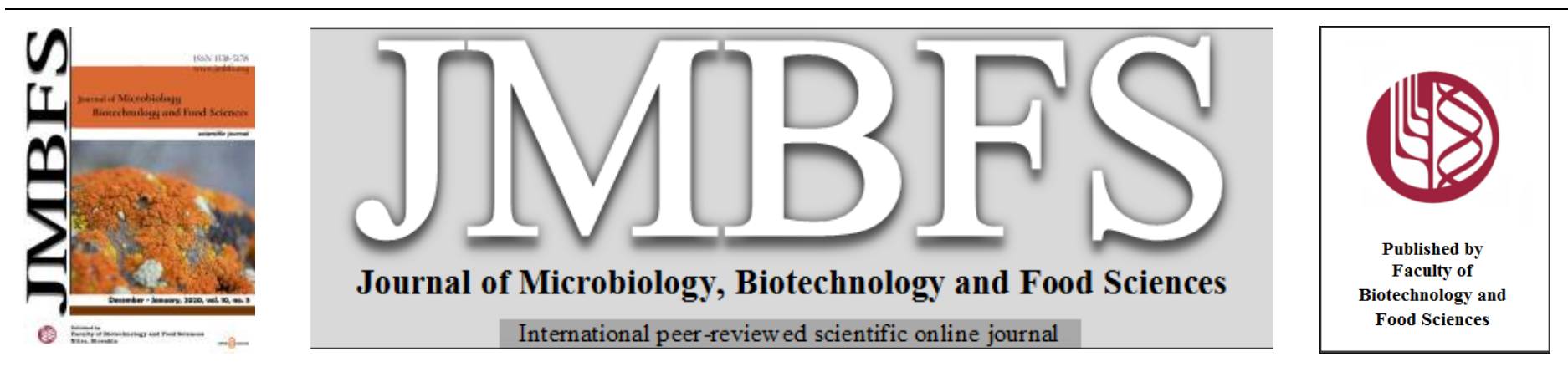

\title{
THE COMBINED EFFECT OF TEMPERATURE, pH AND LACTOSE CONCENTRATION ON THE GROWTH PROBABILITY OF LISTERIA INNOCUA
}

\author{
Cansu Leylak, Sencer Buzrul* \\ Address(es): \\ Department of Food Engineering, Konya Food and Agriculture University, Konya, Turkey.
}

*Corresponding author: sencer.buzrul@gidatarim.edu.tr

doi: $10.15414 / j m b f s .2020 .10 .3 .474-477$

\section{ARTICLE INFO}

Received 11. 4. 2020

Revised 22. 9. 2020

Accepted 24. 9. 2020

Published 1. 12. 2020

Regular article

open $\partial_{\text {access }}$

\begin{abstract}
Growth response data of Listeria innocua in broth were monitored at different combinations of temperature $\left(4,8\right.$ and $\left.12{ }^{\circ} \mathrm{C}\right), \mathrm{pH}(4.0$, $4.5,5.0,5.5$ and 6.0) and lactose concentration $[0,1,2,3,4$ and $5(\mathrm{w} / \mathrm{v} \%)]$ for 35 days. Especially low levels of temperat ure and $\mathrm{pH}$ were effective to prevent the growth of $L$. innocua whereas lactose concentration should be at least $\geq 4 \%$ at low temperature and $\mathrm{pH}$ values to obtain no growth response. Logistic regression model was developed to describe and further predict the growth boundaries of L. іппосиа under different combinations of the conditions. Goodness-of-fit indices and measures of predictive power such as percent concordant revealed that the fitted equation described the growth limits of $L$. innocua successfully. The proposed model could be also used to predict growth limits or probabilities of Listeria in whey at different temperature levels since $\mathrm{pH}$ and lactose concentration of whey is similar to the conditions tested and this was demonstrated for both sweet whey and acid whey. This study indicated that a quick estimate of growth probability of L. innocua is possible at different combinations of temperature, $\mathrm{pH}$ and lactose concentration.
\end{abstract}

Keywords: Predictive microbiology, probabilistic models, growth/no growth, Listeria monocytogenes

\section{INTRODUCTION}

Listeriae are gram-positive, nonsporulating, psychrotrophic and facultative anaerobic bacteria, and can grow over a wide range of temperature (optimum growth temperature is between 30 and $37{ }^{\circ} \mathrm{C}$ ) and $\mathrm{pH}$ (4.1-9.6). Due to their ability to form biofilms on various surfaces, Listeriae can be commonly found in food processing facilities and equipment (Ferreira et al., 2016). Listeria monocytogenes is the specie responsible for listeriosis in humans which is a health concern throughout the world.

Different names such as growth/no growth interface, growth boundary models have been attributed to the probabilistic models which are used to define and predict the growth limits of microorganisms under various environmental conditions (Haberbeck et al., 2015). Predictive growth/no growth modeling have been successfully applied during the last 25 years, and logistic regression technique is generally used to define the growth boundaries of microorganisms although other techniques such as artificial neural networks (Hajmeer and Basheer, 2003) and growth/no growth model derived from the Gamma model (Polese et al., 2011) were also applied. This type of models could be very beneficial to food industry by giving a quick estimate of chance of growth under a set of environmental factors such as temperature as well as intrinsic factors such as $\mathrm{pH}$ and water activity of the food.

Production of different cheese varieties such as Salamoura (Turkey), Feta (Greece), Telemea (Greece, Rumania), and Domiati (Egypt) from raw milk is a common practice in some countries (Papageorgiou and Marth, 1989). Although these cheeses are brined and matured for several months to prevent the pathogen survival, pathogens may pass through whey during production of cheese. Dairy foods, especially cheeses are the major causes of listeriosis outbreaks (Rogers $\boldsymbol{e t}$ al., 2018).

Studies on growth/no growth modeling of different bacteria including $L$. monocytogenes are abundant in literature; however, to the best our knowledge there is no study on the combined effect of temperature, $\mathrm{pH}$ and lactose concentration. Lactose and $\mathrm{pH}$ levels may be important for the growth of Listeria in dairy products such as whey. Therefore, the objective of this study was to develop a probabilistic model to define the growth limits of $L$. innocua which is a non-pathogenic bacterium and a surrogate for $L$. monocytogenes due to its genetic similarity (Sheng et al., 2020).

\section{MATERIALS AND METHODS}

\section{Bacterial strain and inoculum preparation}

L. innocua strain ATCC 33090 was used in this study. The strain was stored at $80{ }^{\circ} \mathrm{C}$ in tryptic soy broth (TSB; 7164 , Acumedia) supplemented with $0.6 \%$ yeast extract (YE; 7184A, Acumedia) and $15-20 \%$ glycerol. Frozen culture was activated in TSBYE at $30^{\circ} \mathrm{C}$ for $24 \mathrm{~h}$, and a subculture was taken twice and incubated in TSBYE for $24 \mathrm{~h}$ at $30^{\circ} \mathrm{C}$. An inocula $(100 \mu \mathrm{L})$ from the activated culture, which was at the stationary phase $\left(21 \mathrm{~h}\right.$ at $\left.30^{\circ} \mathrm{C}\right)$, was transferred to 10 $\mathrm{mL}$ of TSBYE to obtain $10^{8}-10^{9} \mathrm{CFU} / \mathrm{mL}$.

\section{Experimental design}

A full factorial design with three temperatures $\left(4,8\right.$ and $\left.12{ }^{\circ} \mathrm{C}\right)$, four $\mathrm{pH}$ levels $(4.5,5.0,5.5$ and 6.0$)$ and six lactose concentrations $[0,1,2,3,4$ and $5 \%(\mathrm{w} / \mathrm{v})]$ was used. Each treatment was tested twice, resulting in a total of 144 data points ( 3 temperatures $\times 4 \mathrm{pH} \times 6$ lactose $\times 2$ replication). The $\mathrm{pH}$ and lactose levels were selected to simulate whey properties.

For each combination, TSBYE $(10 \mathrm{~mL})$ was inoculated to about $10^{6} \mathrm{CFU} / \mathrm{mL}$ by diluting the previously prepared inocula using sterile peptone water (LAB 104 , Lab M). The $\mathrm{pH}$ of the TSBYE was adjusted with appropriate values with $1 \mathrm{~N}$ $\mathrm{HCl}$. At first, lactose concentration was adjusted to $5 \%$ for each TSBYE with different $\mathrm{pH}$. Broth solutions were filter-sterilized with $0.2 \mu \mathrm{m}$ membrane filter system under vacuum (10040-464, VWR). After sterilization, solutions were serially diluted to 4, 3, 2 and $1 \%$ of lactose. Uninoculated samples (with adjusted $\mathrm{pH}$ and containing lactose) were served as negative controls and TSBYE $(\mathrm{pH}=$ 7.2 with no lactose) inoculated with $10^{6} \mathrm{CFU} / \mathrm{mL}$ bacteria was used as the positive control.

\section{Growth assessment}

Microbial growth i.e., presence/absence of growth was monitored weekly by measuring the optical density of the media at $600 \mathrm{~nm}$ using a microplate reader $\left(\mathrm{BTH} 1 \mathrm{M}\right.$, Biotek $^{\mathrm{TM}}$ ) for 35 days. Media in the glass tubes with all combinations and inoculated with L. innocua were shaken manually, and $200 \mu \mathrm{L}$ from each tube was transferred into 96-wells plate with lid. Positive and negative controls were also transferred. Before reading the optical density linear mixing was applied for $10 \mathrm{~s}$. A tube was considered as showing growth if the optical density 
had increased by at least 0.1 above the optical density at time zero (Khanipour $\boldsymbol{e}$ al., 2016a). Growth was also verified by spread plating onto a tryptone soy agar (TSA; LAB 011, Lab M) supplemented with $0.6 \%$ yeast extract and Listeriaselective (Palcam) agar (LAB 148, Lab M).

\section{Model development}

Growth or no growth responses of L. innocua were scored as 1 or 0 , respectively. Data were fitted to a logistic regression model using SPSS (Version 22, Chicago, IL, USA). Two models were proposed:

$$
\begin{gathered}
\operatorname{logit}(p)=a_{0}+a_{1} \cdot T+a_{2} \cdot p H+a_{3} \cdot L C+a_{4} \cdot T \cdot p H+a_{5} \cdot T \cdot L C+a_{6} \\
p H \cdot L C+a_{7} \cdot T \cdot p H \cdot L C
\end{gathered}
$$

where $\operatorname{logit}(p)$ is $\ln [p /(1-p)], p$ is the probability of growth in the range of 0 to 1 , $a_{\mathrm{i}}$ are the coefficients to be estimated, $T\left({ }^{\circ} \mathrm{C}\right)$ is temperature, $p H$ is the initial $\mathrm{pH}$ of the medium and $L C$ is the lactose concentration (w/v \%).

Ratkowsky and Ross (1995) proposed to use logarithmic terms for temperature $\mathrm{pH}$ and water activity on the right hand side of the logistic equation and therefore as a second model:

$$
\begin{aligned}
& \operatorname{logit}(p)=b_{0}+b_{1} \cdot \ln \left(T-T_{\text {min }}\right)+b_{2} \cdot \ln \left(p H-p H_{\text {min }}\right)+b_{3} \cdot L C+b_{4} \\
& \ln \left(T-T_{\text {min }}\right) \cdot \ln \left(p H-p H_{\text {min }}\right)+b_{5} \cdot \ln \left(T-T_{\text {min }}\right) \cdot L C+b_{6} \cdot \ln (p H- \\
& \left.p H_{\text {min }}\right) \cdot L C+b_{7} \cdot \ln \left(T-T_{\text {min }}\right) \cdot \ln \left(p H-p H_{\text {min }}\right) \cdot L C
\end{aligned}
$$

where $T_{\min }$ and $p H_{\min }$ are the minimum notional temperature and $\mathrm{pH}$, respectively; and $b_{\mathrm{i}}$ are the coefficients to be estimated. Minimum lactose concentration $\left(L C_{\text {min }}\right)$ were not placed in Eq.(2) because lactose is not an essential component for Listeria to grow. Moreover, although lactose concentration may affect the water activity of an aqeous solution the concentration range $(0-5 \%)$ that we used had no impact on the water activity. Both $T_{\min }$ and $p H_{\min }$ can be estimated from regression or can be treated as fixed constants (Ratkowsky, 2002). Le Marc et al. (2002) obtained $T_{\min }$ as $-4.5^{\circ} \mathrm{C}$ and $p H_{\min } 4.21$ for the same $L$. innocua strain (ATCC 33090). Frozen temperature as the minimum growth temperature of L.innocua may seem odd; however, substantial growth of L. monocytogenes was reported at subzero temperatures: $-2.2{ }^{\circ} \mathrm{C}$ in broth (Bajard et al., 1996) and -0.4 ${ }^{\circ} \mathrm{C}$ in chicken broth (Walker et al., 1990)

Modeling was done as follows: (i) regression was applied with all the coefficients in the model, (ii) if any coefficient (or coefficients) was insignificant $(P \geq 0.05)$, then it was removed from the model and regression was repeated without it. Only one insignificant coefficient was removed before each regression and this was repeated until there were no insignificant coefficients left in the model i.e. remaining coefficients in the model were all significant $(P<0.05)$. The predicted growth/no growth interfaces for different growth probabilities were plotted by using Microsoft ${ }^{\circledR}$ Excel Solver.

\section{Evaluation of the model performance}

Proposed models were assessed by $-2 \cdot \ln L$ with $L$ the likehood in its optimum, Hosmer-Lemeshow (H-L) statistic, maximum rescaled $\mathrm{R}^{2}$ statistic and percen concordant. The First statistic $(-2 \cdot \ln L)$ can be used to rank the models according to their goodness-of-fit, but does not give an idea about the adequacy of the model fit (Dang et al., 2010). Small values of $-2 \cdot \ln L$ correspond to better fitting models (Gysemans et al., 2007). The H-L $P$ value indicates how well the logistic regression equation fits the data by comparing the number of individuals with each outcome with the number expected based on the logistic equation. If H-L statistic takes a small value or its corresponding $P$ value is high, then the model fits the data adequately. The maximum rescaled $\mathrm{R}^{2}$ indicates how useful the independent variables are in describing the response variable (Bewick et al., 2005) and percent concordance reflects the correspondence between observed and fitted values (Dang et al., 2010).

\section{RESULTS AND DISCUSSION}

Growth response data (1: growth, 0: no growth) of $L$. innocua were monitored at different temperature, $\mathrm{pH}$ and lactose concentrations for 5 weeks (35 days), and no increase in OD values of negative controls during this period was observed indicating that there was no contaimination during the preparation of the liquid media. On the other hand, OD values of the positive control increased as expected.

Change of growth/no growth responses at different temperature, $\mathrm{pH}$ and lactose concentration with respect to time

Fig. 1 shows the growth/no growth responses of $L$. innocua in broth containing 5 $\%$ lactose at different temperature and $\mathrm{pH}$ values. Growth was observed at $12{ }^{\circ} \mathrm{C}$ for all $\mathrm{pH}$ values except the $\mathrm{pH} 4.5$ at the $5^{\text {th }}$ day (Fig. 1b) and growth at $12{ }^{\circ} \mathrm{C}$ could not be prevented even at the lowest $\mathrm{pH}$ value $(\mathrm{pH}=4.5)$ at day 10 i.e., at $12{ }^{\circ} \mathrm{C}$ all growth responses were 1 for all $\mathrm{pH}$ levels (Fig. 1c). Note that there were no changes in growth/no growth responses between the days 16 and 35 . Growth was not observed at $8{ }^{\circ} \mathrm{C}, \mathrm{pH}=4.5$, and at $4{ }^{\circ} \mathrm{C}, \mathrm{pH}=4.5$ and 5.0 (Fig 1d)

It is known that L. monocytogenes can grow well even at refrigeration temperatures $\left(<5{ }^{\circ} \mathrm{C}\right)$ or at low $\mathrm{pH}$ values (4.4) (Montiel et al., 2020); however, combining both conditions i.e., low temperature + low $\mathrm{pH}$ may prevent the growth of Listeria (Fig. 1). Among the three conditions studied lactose was the least effective one. High concentrations of lactose reduce the water activity of a solution and therefore may prevent the growth of bacteria; however, even at $5 \%$ (w/w) lactose concentration water activity of an aqueous solution was still higher than 0.99 (Miracco et al., 1981). It seemed that lactose to a extend did not effect the growth since L. monocytogenes can grow even at lower water activity values (Vermeulen et al., 2007). Lower temperature $\left(<8{ }^{\circ} \mathrm{C}\right)$ and $\mathrm{pH}(<5.0)$ values had an impact on the growth of $L$. innocua regardless of lactose concentration in broth, whereas high lactose concentration $(\geq 4 \%)$ was only effective at $4{ }^{\circ} \mathrm{C}, \mathrm{pH}$ $=4.5$ and 5.0 - results not shown. McKellar and Lu (2001) also observed that sucrose up to $8 \%$ had no impact on the growth of Escherichia coli O157:H7 however, temperature, $\mathrm{pH}$, salt and acetic acid had significant effect.

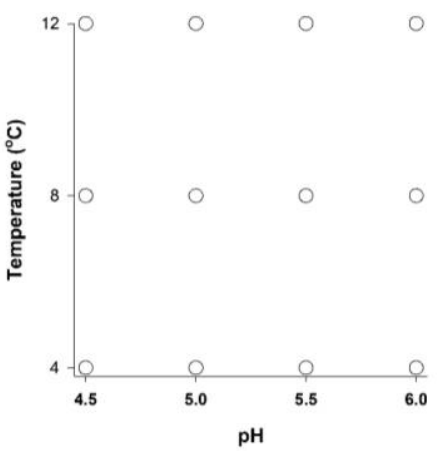

(c)

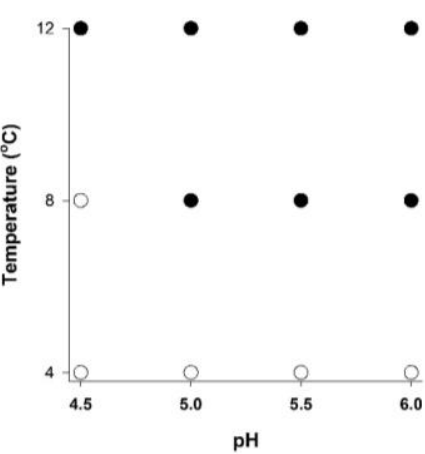

(b)

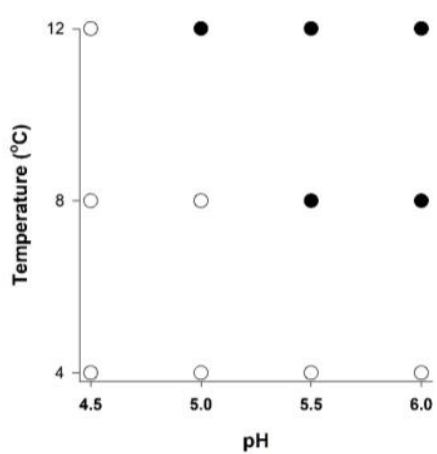

(d)

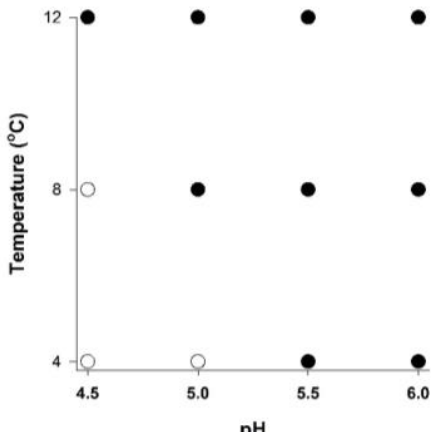

Figure 1 Growth (black circles) and no growth (white circles) data of Listeria innocua $\left(10^{6} \mathrm{CFU} / \mathrm{mL}\right)$ in broth containing $5 \%$ lactose at different temperature and $\mathrm{pH}$ levels with respect to time: $0^{\text {th }}$ day (a), $5^{\text {th }}$ day (b), $10^{\text {th }}$ day (c), and days between 16 and $35(\mathrm{~d})$.

\section{Model identification}

Following logistic regression models [Eqs. (3) and (4)] were obtained:

$$
\begin{aligned}
& \operatorname{logit}(p)=-4.222+0.192 \cdot T \cdot p H-0.155 \cdot T \cdot L C+0.155 \cdot p H \cdot L C \\
& \operatorname{logit}(p)=8.218+2.797 \cdot \ln \left(T-T_{\text {min }}\right) \cdot \ln \left(p H-p H_{\text {min }}\right)+46.428 \cdot \\
& \quad \ln \left(p H-p H_{\text {min }}\right) \cdot L C-17.663 \cdot \ln \left(T-T_{\text {min }}\right) \cdot \ln \left(p H-p H_{\text {min }}\right) \cdot L C
\end{aligned}
$$

where $T_{\min }=-4.5^{\circ} \mathrm{C}$ and $p H_{\min }=4.21$

The coefficients of the models with their standard error and $P$ values are given in Table 1. It can be seen that second model i.e., model with logarithmic terms [Eq.(4)] had better fit than the first model [Eq.(3)] because it had lower $-2 \cdot \ln L$ value, smaller H-L statistic and higher $P$ value, much higher maximum rescaled $\mathrm{R}^{2}$ statistic and percent concordant. In fact, first model was completely useless because its maximum rescaled $\mathrm{R}^{2}$ was 0.430 and its concordance was $84.7 \%$ Therefore, Eq.(4) was further used to plot the predicted growth/no growth interfaces of $L$. innocua. Boundaries for likely to grow probability $(p=0.9)$, equal probability of growth and no growth $(p=0.5)$ and unlikely to grow probability $(p=0.1)$ are displayed in Fig. 2. 
Table 1 Coefficients of the models together with their standard error (S.E.) and P values, and goodness-of-fit indices of the models

\begin{tabular}{|c|c|c|c|c|c|c|c|}
\hline \multicolumn{4}{|c|}{ Model 1 [Eq.(1)] } & \multicolumn{4}{|c|}{ Model 2 [Eq.(2)] } \\
\hline Coefficient & Value & S.E. & $\mathrm{P}$ value & Coefficient & Value & S.E. & $\mathrm{P}$ value \\
\hline$a_{0}$ & -4.222 & 1.159 & $<0.001$ & $b_{0}$ & 8.218 & 2.716 & 0.002 \\
\hline$a_{1}$ & $-^{a}$ & - & - & $b_{1}$ & - & - & - \\
\hline$a_{2}$ & - & - & - & $b_{2}$ & 一 & - & - \\
\hline$a_{3}$ & - & - & - & $b_{3}$ & - & - & - \\
\hline$a_{4}$ & 0.192 & 0.045 & $<0.001$ & $b_{4}$ & 2.797 & 0.952 & 0.003 \\
\hline$a_{5}$ & -0.155 & 0.049 & 0.001 & $b_{5}$ & 一 & - & 一 \\
\hline$a_{6}$ & 0.155 & 0.056 & 0.006 & $b_{6}$ & 46.428 & 16.226 & 0.004 \\
\hline$a_{7}$ & 一 & - & - & $b_{7}$ & -17.663 & 6.263 & 0.005 \\
\hline$-2 \cdot \ln L^{b}$ & 96.583 & & & $-2 \cdot \ln L$ & 17.213 & & \\
\hline $\mathrm{H}-\mathrm{L}^{c}$ & $\begin{array}{l}11.256(\mathrm{P}= \\
0.188)\end{array}$ & & & H-L & $0.197(\mathrm{P}=1.000)$ & & \\
\hline $\max$ rescaled $\mathrm{R}^{2}$ & 0.431 & & & $\begin{array}{l}\max \text { rescaled } \\
\mathrm{R}^{2}\end{array}$ & 0.924 & & \\
\hline concordant & $84.7 \%$ & & & concordant & $97.2 \%$ & & \\
\hline
\end{tabular}

${ }^{b}$ L: likelihoo

H-L: Hosmer-Lemeshow statistic

Note that main effects $(T, p H$ and $L)$ were not significant $(P \geq 0.05)$ and only interaction terms existed in both models i.e., Eq.(3) and Eq.(4) (Table 1). Normally, in logistic regression models main effects (temperature, $\mathrm{pH}$ and lactose concentration in our case) are forced to stay in the model (Buzrul, 2019 Daelman et al., 2013); however, these effects had high $\mathrm{P}$ values $(\mathrm{P} \geq 0.98)$ so that standard errors of the coefficients were even higher than the coefficients themselves. Therefore, main effects were removed from the model and regression was repeated until a model with significant terms obtained. To the best of ou knowledge, this study was the first where the interaction terms stayed in the model while main effects were removed from the model.

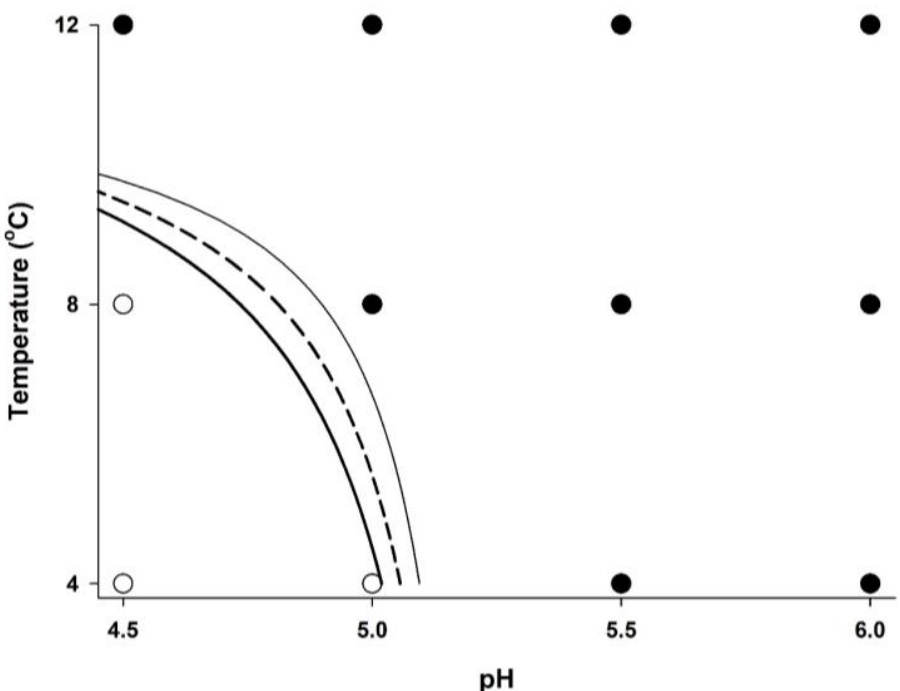

Figure 2 Growth (black circles)/no growth (white circles) interface of Listeria innocua $\left(10^{6} \mathrm{CFU} / \mathrm{mL}\right)$ in broth containing $5 \%$ lactose at different temperature and $\mathrm{pH}$ levels at the end of 5 weeks. Thin solid line, dashed line and thick solid line represent the growth probabilities of $0.9,0.5$ and 0.1 , respectively according to Eq.(4).

The growth/no growth interfaces were consistent with the experimental data (Fig. 2 ). It could be also possible to predict the outcome of other conditions than the experimental levels within the extrapolation region by using Eq.(4). For example, when $T=6.2{ }^{\circ} \mathrm{C}, p H=4.8$ and $L C=4.7 \%$ in Eq.(4) $p=0.0014$ indicating the growth probability is very low and one may consider that under these conditions $L$. innocua and most probably $L$. monocytogenes would not grow. On the other hand, when $T=9{ }^{\circ} \mathrm{C}, p H=5.2$ and $L C=2.5 \%$ in Eq.(4) $p=0.999$, so these conditions favor the growth of Listeria.

Fig. 3 shows the growth probability of $L$. innocua in liquid media which have $4.6 \%$ lactose $(\mathrm{w} / \mathrm{v})$ and $\mathrm{pH}=6.0$ (sweet whey analogue), and $4.6 \%$ lactose $(\mathrm{w} / \mathrm{v})$ and $\mathrm{pH}=4.7$ (acid whey analogue), respectively with respect to temperature.

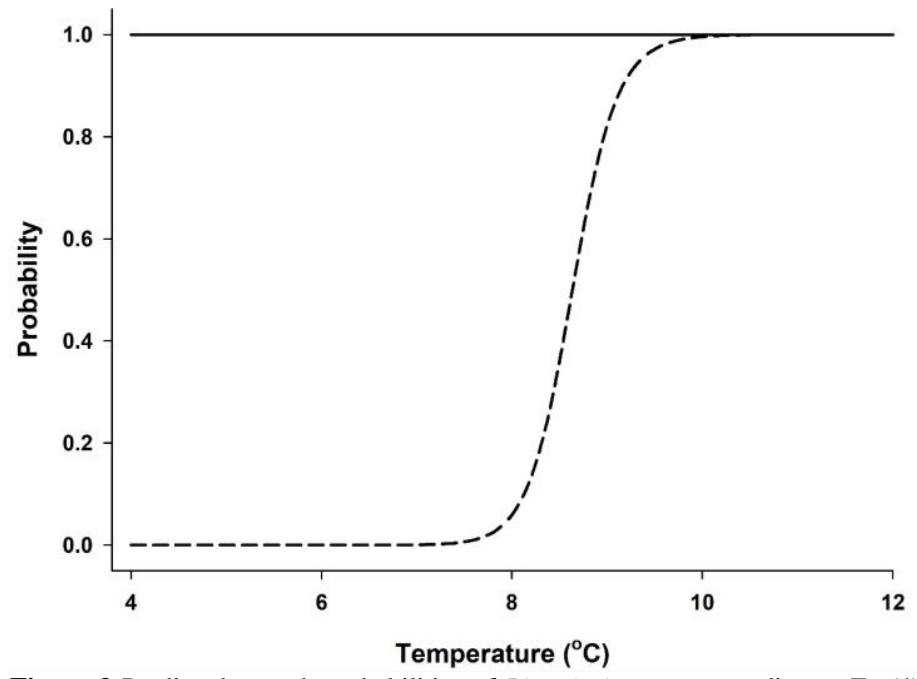

Figure 3 Predicted growth probabilities of Listeria innocua according to Eq.(4) with respect to temperature: solid line represents a liquid medium containing 4.6 $\%$ lactose (w/v) and $\mathrm{pH} 6.0$ (sweet whey analogue) and dashed line represents a liquid medium containing $4.6 \%$ lactose (w/v) and $\mathrm{pH} 4.7$ (acid whey analogue).

While proposed model [Eq.(4)] could be also used to predict the growth probability of Listeria in whey since $\mathrm{pH}$ and lactose concentration of whey is similar to the conditions tested in this study, it should be noted that the inoculum size $\left(10^{6} \mathrm{CFU} / \mathrm{mL}\right)$ was higher than the expected contamination of whey and therefore it may be supposed that growth probability under realistic conditions would be less (Khanipour et al., 2016b). Moreover, liquid whey has some other components than lactose such as amino acids and minerals which may also effect the growth of bacteria. Sweet whey has $\mathrm{pH}$ values of 6.0-7.0 and lactose concentrations of $4.6-5.2 \%(\mathrm{w} / \mathrm{v})$ while acid whey has $\mathrm{pH}<5.0$ and lactose concentrations of 4.4-4.6\% (w/v) (Panesar and Kennedy, 2012). Considering those limits one can plot the probability of growth of $L$. innocua with respect to any condition such as Fig. 3 by using Eq.(4). It is apparent that Listeria could grow in sweet whey $(\mathrm{pH}=6.0)$ whatever the temperature value was between 4-12 ${ }^{\circ} \mathrm{C}$; however, in acid whey $(\mathrm{pH}=4.7)$ growth probability was equal to or almost zero up to $8{ }^{\circ} \mathrm{C}$. Furthermore, growth probability increased drastically between 8 and $9{ }^{\circ} \mathrm{C}$ indicating that low $\mathrm{pH}(<5.0)$ in combination with refrigeration temperature $\left(<8{ }^{\circ} \mathrm{C}\right)$ could be used to avoid Listeria growth in acid whey (Fig. $3)$. Note that the results were extended from broth to whey. However, there may be deviations from the results obtained in the laboratory medium compared to a real food system.

Growth/no growth modeling has been applied since the mid-90s and there are numerous researches available on different bacteria including $L$. monocytogenes Temperature, $\mathrm{pH}$ and water activity (generally adjusted with $\mathrm{NaCl}$ ) are the most popular conditions to determine the growth boundaries; however, inoculum size (Koutsoumanis and Sofos, 2005), acetic acid (Vermeulen et al., 2007), lactic acid (Tienungoon et al., 2000; Yoon et al., 2009), $\mathrm{NaNO}_{2}$ (Gwak et al., 2015), citric and ascorbic acids (Valero et al., 2006), and sodium lactate and sodium acetate (Skandamis et al., 2007) were also studied together with those factors to define the growth limits of L. monocytogenes. 
There are limited number of studies on the growth of Listeria in whey in literature. Ryser and Marth (1988) found that two out of four strains of $L$ monocytogenes (Scott A, V7, CA and $\mathrm{OH}$ ) can grow in whey (obtained from Camembert cheese and $\mathrm{pH}$ was adjusted to 5.0-6.8) at $6{ }^{\circ} \mathrm{C}$ and below $\mathrm{pH} 5.4$ von Staszewski and Jagus (2008) observed immediate growth of L. innocua in liquid cheese whey system at $7{ }^{\circ} \mathrm{C}$ with $\mathrm{pH}$ adjusted to 5.5. These studies also confirmed the results obtained here (Figs. 1 and 2).

\section{CONCLUSION}

This study revealed that growth probability of $L$. innocua in broth supplemented with lactose $(0-5 \%)$ at different $\mathrm{pH}(4.5-6.0)$ and temperature $\left(4-12^{\circ} \mathrm{C}\right)$ could be successfully described by logistic regression model. Further prediction of growth boundaries could also be possible (Fig. 2). Because the whey has a $\mathrm{pH}$ range of 4.6 to 7.0 , and lactose ( 4.4 to $5.2 \%$ ), protein source and minerals in it, it could be a suitable environment for the growth of L. monocytogenes, especially if the cheese is produced from raw milk. However, storage temperature of whey is crucial and a rapid growth would not be surprising at temperatures $>8{ }^{\circ} \mathrm{C}$. We believed that the obtained results are important because Listeria can grow or survive under harsh environmetal conditions such as refrigeration temperatures, high salt levels and acidic $\mathrm{pH}$ range in the presence or absence of oxygen

Acknowledgments: This study was supported by Konya Food and Agriculture University, Scientific Research Project Coordinator, project no. BAP-2019/0028 Authors thank Onur Bulut for his help during the usage of microplate reader and preparation of the media.

\section{REFERENCES}

Bajard, S., Rosso, L., Fardel, G., \& Flandrois, J.P. (1996). The particular behaviour of Listeria monocytogenes under sub-optimal conditions. International Journal of Food Microbiology 29, 201-211. https://doi.org/10.1016/01681605(95)00031-3

Bewick, V., Cheek, L., \& Ball, J. (2005). Statistical Review 14: Logistic regression. Critical Care 9, 112-118. https://doi.org/10.1186/cc3045.

Buzrul, S. (2019). High hydrostatic pressure inactivation of microorganisms: A probabilistic model for target log-reductions. International Journal of Food Microbiology 309, 108330. https://doi.org/10.1016/j.ijfoodmicro.2019.108330.

Daelman, J., Vermeulen, A., Willemyns, T., Ongenaert, R., Jacxsens, L. et al. (2013). Growth/no growth models for heat-treated psychrotrophic Bacillus cereu spores under cold storage. International Journal of Food Microbiology 161, 7 15. https://doi.org/10.1016/j.ijfoodmicro.2012.11.017.

Dang, T.D.T., Mertens, L., Vermeulen, A., Geeraerd, A.H., Van Impe, J.F. et al (2010). Modelling the growth/no growth boundary of Zygosaccharomyces baili in acidic conditions: A contribution to the alternative method to preserve foods without using chemical preservatives. International Journal of Food Microbiology 137, 1-12. https://doi.org/10.1016/j.ijfoodmicro.2009.10.020.

Ferreira, M., Almeida, A., Delgadillo, I., Saraiva, J., \& Cunha, A. (2016) Susceptibility of Listeria monocytogenes to high pressure processing. Food Reviews International $\quad 4,377-379$. https://doi.org/10.1080/87559129.2015.1094816.

Gysemans, K.P.M., Bernaerts, K., Vermeulen, A., Geeraerd, A.H., Debevere, J. et al. (2007). Exploring the performance of logistic regression model types on growth/no growth data of Listeria monocytogenes. International Journal of Food Microbiology 114, 316-331. https://doi.org/10.1016/j.ijfoodmicro.2006.09.026.

Gwak, E., Oh, M.-H., Park, B.-Y., Lee, H., Lee, S. et al. (2015). Probabilistic models to predict Listeria monocytogenes growth at low concentrations of $\mathrm{NaNO}_{2}$ and $\mathrm{NaCl}$ in frankfurters. Korean Journal for Food Science of Animal Resources 35, 815-823. https://doi.org/10.5851/kosfa.2015.35.6.815.

Haberbeck, L.U., Oliveira, R.C., Vivijs, B., Wenseleers, T., Aertsen, A. et al (2015). Variability in growth/no growth boundaries of 188 different Escherichia coli strains reveals that approximately $75 \%$ have a higher growth probability under low pH conditions than E. coli O157:H7 strain ATCC 43888. Food Microbiology 45, 222-230. https://doi.org/10.1016/j.fm.2014.06.024.

Hajmeer, M., \& Basheer, I. (2003). A probabilistic neural network approach for modeling and classification of bacterial growth/no-growth data. Journal of Microbiological Methods 51, 217-226. https://doi.org/10.1016/S01677012(02)00080-5.

Khanipour, E., Flint, S.H., McCarthy, O.J., Golding, M., Palmer, J. et al. (2016a) Modelling the combined effects of salt, sorbic acid and nisin on the probability of growth of Clostiridium sporogenes in a controlled environment (nutrient broth). Food Control 62, 32-43. https://doi.org/ 10.1016/j.foodcont.2015.10.012.

Khanipour, E., Flint, S.H., McCarthy, O.J., Palmer, J., Golding, M. et al. (2016b) Modelling the combined effect of salt, sorbic acid and nisin on the probability of growth of Clostiridium sporogenes in high moisture processed cheese analogue. International Dairy Journal 57, 62-71. https://doi.org/ 10.1016/j.idairyj.2016.02.039.

Koutsoumanis, K.P., \& Sofos, J.N. (2005). Effect of inoculum size on the combined temperature, $\mathrm{pH}$ and $\mathrm{a}_{\mathrm{w}}$ limits for growth of Listeria monocytogenes
International Journal of Food Microbiology 104, 83-91. https://doi.org/10.1016/j.ijfoodmicro.2005.01.010.

Le Marc, Y., Huchet, V., Bourgeois, C.M., Guyonnet, J.P., \& Mafart, P. (2002). Modelling the growth kinetics of Listeria as a function of temperature, $\mathrm{pH}$ and organic acid concentration. International Journal of Food Microbiology 73, 219237. https://doi.org/10.1016/S0168-1605(01)00640-7.

McKellar, R.C., \& Lu, X. (2001). A probability of growth model for Escherichia coli $\mathrm{O} 157: \mathrm{H} 7$ as a function of temperature, $\mathrm{pH}$, acetic acid, and salt. Journal of Food Protection 12, 1922-1928. https://doi.org/10.4315/0362-028x-64.12.1922. Miracco, J.L., Alzamora, S.M., Chirife, J., \& Fontan, C.F. (1981). On the water activity of lactose solutions. Journal of Food Science 46, 1612-1613. https://doi.org/10.1111/j.1365-2621.1981.tb04231.x.

Montiel, R., Peiroten, A., Ortiz, S., Bravo, D., \& Gaya, P. (2020). Inactivation of Listeria monocytogenes during dry-cured ham processing. International Journal

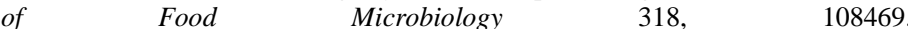
https://doi.org/10.1016/j.ijfoodmicro.2019.108469.

Panesar, P.S., \& Kennedy, J.F. (2012). Biotechnological approaches for the value addition of whey. Critical Reviews in Biotechnology 32, 327-348. https://doi.org/10.3109/07388551.2011.640624.

Papageorgiou, D.K., \& Marth, E.H. (1989). Behavior of Listeria monocytogenes at 4 and $22{ }^{\circ} \mathrm{C}$ in whey and skim milk containing 6 or $12 \%$ sodium chloride. Journal of Food Protection 52, 625-630. https://doi.org/0.4315/0362-028X52.9.625.

Polese, P., Del Torre, M., Spaziani, M., \& Stecchini, M.L. (2011). A simplified approach for modelling the bacterial growth/no growth boundary. Food Microbiology 28, 384-391. https://doi.org/10.1016/j.fm.2010.09.011.

Ratkowsky, D.A., \& Ross, T. (1995). Modelling the bacterial growth/no growth interface. Letters in Applied Microbiology 20, 2933. https://doi.org/10.1111/j.1472-765X.1995.tb00400.x.

Ratkowsky, D.A. (2002). Some examples of, and some problems with, the use of nonlinear logistic regression in predictive food microbiology. International Journal of Food Microbiology 73, 119-125. https://doi.org/10.1016/s01681605(01)00643-2.

Rogers, S.A., Calicchia, M., \& Hellberg, R.S. (2018). Concentration of Listeria monocytogenes in skim milk and soft cheese through microplate immunocapture. Journal of Microbiological Methods 153, 54-59. https://doi.org/10.1016/j.mimet.2018.09.005.

Ryser, E.T., \& Marth, E.H. (1988). Growth of Listeria monocytogenes at different $\mathrm{pH}$ values in uncultured whey or whey cultured with Penicillium camemberti. Canadian Journal of Microbiology 34, 730-734. https://doi.org/10.1139/m88-124.

Sheng, L., Shen, X., \& Zhu, M.-J. (2020). Screening of non-pathogenic surrogates of Listeria monocytogenes applicable for chemical antimicrobial interventions of fresh apples. Food Control 110, 106977. https://doi.org/10.1016/j.foodcont.2019.106977.

Skandamis, P.N., Stopforth, J.D., Yoon, Y., Kendall, P.A., \& Sofos, J.N. (2007) Modeling the effect of storage atmosphere on growth-no growth interface of Listeria monocytogenes as a function of temperature, sodium lactate, sodium diacetate and $\mathrm{NaCl}$. Journal of Food Protection 70, 2329-2338. https://doi.org/10.4315/0362-028x-70.10.2329.

Tienungoon, S., Ratkowsky, D.A., McMeekin, T.A., \& Ross, T. (2000). Growth limits of Listeria monocytogenes as a function of temperature, $\mathrm{pH}, \mathrm{NaCl}$, and lactic acid. Applied and Environmental Microbiology 66, 4979-4987. https://doi.org/10.1128/aem.66.11.4979-4987.2000.

Valero, A., Carrasco, E., Perez-Rodriguez, F., Garcia-Gimeno, R.M., \& Zurera, G. (2006). Growth/no growth model of Listeria monocytogenes as a function of temperature, pH, citric acid and ascorbic acid. European Food Research and Technology 224, 91-100. https://doi.org/10.1007/s00217-006-0293-1.

Vermeulen, A., Gysemans, K.P.M., Bernaerts, K., Geeraerd, A.H., Van Impe, J.F. et al. (2007). Influence of $\mathrm{pH}$, water activity and acetic acid concentration on Listeria monocytogenes at $7{ }^{\circ} \mathrm{C}$ : Data collection for the development of a growth/no growth model. International Journal of Food Microbiology 114, 332 341. https://doi.org/10.1016/j.ijfoodmicro.2006.09.023.

von Staszewski, M., \& Jagus, R.J. (2008). Natural antimicrobials: Effect of Microgard $^{\mathrm{TM}}$ and nisin against Listeria innocua in liquid cheese whey. $\begin{array}{llll}\text { International Dairy } & \text { Journal } & 18, & 255-259 .\end{array}$ https://doi.org/10.1016/j.idairyj.2007.08.012.

Walker, S.J., Archer, P., \& Banks, J.G. (1990). Growth of Listeria monocytogenes at refrigeration temperatures. Journal of Applied Bacteriology 68, 157-162. https://doi.org/10.1111/j.1365-2672.1990.tb02561.x.

Yoon, Y., Kendall, P.A., Belk, K.E., Scanga, J.A., Smith, G.C. et al. (2009). Modeling the growth/no growth boundaries of postprocessing Listeria monocytogenes contamination on frankfurters and bologna treated with lactic acid. Applied and Environmental Microbiology 75, 353-358. https://doi.org/10.1128/AEM.00640-08. 